\title{
Brilliant Cresyl Blue stain selects largest oocytes with highest mitochondrial activity, maturation-promoting factor activity and embryo developmental competence in prepubertal sheep
}

\author{
Maria Gracia Catalá, Dolors Izquierdo, Svetlana Uzbekova ${ }^{1}$, Roser Morató ${ }^{2}$, Montserrat Roura, \\ Roser Romaguera, Pascal Papillier ${ }^{1}$ and Maria Teresa Paramio \\ Departament de Ciència Animal i dels Aliments, Facultat de Veterinària, Universitat Autònoma de Barcelona, \\ Bellaterra, Barcelona, Spain, ${ }^{1}$ Physiologie de la Reproduction et des Comportements, UMR6175 INRA, CNRS, \\ Université de Tours, Haras Nationaux, Nouzilly, France and ${ }^{2}$ Departament de Medicina i Cirurgia Animal, Facultat de \\ Veterinària, Universitat Autònoma de Barcelona, Bellaterra, Barcelona, Spain
}

Correspondence should be addressed to M T Paramio; Email: teresa.paramio@uab.cat

\begin{abstract}
The aim of this study was to test the Brilliant Cresyl Blue (BCB) stain to select prepubertal sheep oocytes for in vitro blastocyst production. Oocyte diameter, mitochondrial activity, maturation-promoting factor (MPF) activity and mRNA relative expression (RE) of genes related to metabolism (ATPase $\mathrm{Na}^{+} / \mathrm{K}^{+}$transporting $\alpha 1$ (ATP1A1) and cytochrome coxidase subunit 1 (COX1)) and constitutive function of the cell (cytoplasmic polyadenylation-element-binding protein $(C P E B)$ and $S 100 A 10$ ) were assessed. Immature oocytes were exposed to different $B C B$ concentrations $(13,26,39$ and $52 \mu \mathrm{M})$ and classified according to their cytoplasm colouration as grown $B C B+(b l u e$ cytoplasm) and growing BCB - (colourless cytoplasm). Staining oocytes with $13 \mu \mathrm{M} \mathrm{BCB}$ during 60 min allows selection of (BCB +) the largest $(123.66 \mu \mathrm{m})$ and most competent oocytes to develop to the blastocyst stage $(21 \%)$ with a higher number of cells $(69.71 \pm 6.19$ S.E.M.) compared with non-stained BCB - oocytes (106.82 $\mu \mathrm{m}, 9 \%$ and $45.91 \pm 3.35$ s.E.M. respectively). Mitochondrial activity, assessed by MitoTracker Orange CMTMRos probe, was significantly higher in BCB + than in BCB - oocytes after in vitro maturation (3369 and $1565 \mathrm{AU}$ respectively). MPF activity was assessed by CDC2 kinase activity assay showing significantly higher activity at metaphase II stage in $B C B+$ than in $B C B-$ oocytes $(1.479 \pm 0.09$ and $1.184 \pm 0.05$ optical density respectively). The genes analysed in this work, ATP1A1, COX1, CPEB and S100A10, did not show significant effect in mRNA RE between BCB selected oocytes. In conclusion, BCB stains larger and more competent oocytes to develop to the blastocyst stage with more active mitochondria and MPF activity and higher blastocyst cell number.
\end{abstract}

Reproduction (2011) 142 517-527

\section{Introduction}

In vitro embryo production is closely related to oocyte source and quality (Rizos et al. 2002, Cognie et al. 2003). Thus, the efficiency of in vitro techniques is low when using prepubertal animals as oocyte donors. Prepubertal oocytes are characterised as having abnormal cytoplasmic maturation and lower ability to achieve the blastocyst stage than those coming from adult donors (Armstrong 2001). This has been shown in cattle (Revel et al. 1995), sheep (O'Brien et al. 1996) and pigs (Peters et al. 2001). Ovaries from prepubertal animals have a high percentage of antral follicles with a diameter smaller than $3 \mathrm{~mm}$ (Martino et al. 1994), making it difficult to release the cumulus-oocyte complexes (COCs) by traditional aspiration. For this reason, oocytes are routinely obtained by slicing the ovary surface, resulting in oocytes with heterogeneous diameter, different COC morphology and at varying stages of atresia. It is known that there is a direct and positive relationship among follicle size, oocyte diameter and embryo development (Gilchrist et al. 1995, Barnes \& Sirard 2000). In prepubertal goats, we have previously shown that oocytes with a diameter larger than $125 \mu \mathrm{m}$ produced higher percentages of blastocyst after IVF (Anguita et al. 2007) and ICSI (Jimenez-Macedo et al. 2007) and oocytes coming from follicles larger than $3 \mathrm{~mm}$ develop to the blastocyst stage in a significantly higher percentage than oocytes from follicles smaller than $3 \mathrm{~mm}$ (Romaguera et al. 2010). Brilliant Cresyl Blue (BCB) stain is known to be a non-invasive methodology that allows the selection of oocytes with larger diameters among a heterogeneous pool. The BCB test determines the intracellular activity of glucose-6-phosphate dehydrogenase (G6PDH), a pentose phosphate pathway enzyme that gradually decreases its activity as oocytes 
reach their growth phase. BCB dye can be reduced by G6PDH activity, therefore oocytes that have reached their growth phase cannot reduce BCB to a colourless compound and exhibit a blue coloured cytoplasm (BCB +). However, growing oocytes are expected to have a high level of G6PDH activity and be able to reduce the blue compound, resulting in a colourless oocyte cytoplasm $(\mathrm{BCB}-)$. In our previous studies in prepubertal goats (Rodriguez-Gonzalez et al. 2002) and cows (Pujol et al. 2004), we have shown the usefulness of the BCB stain to select the larger and more competent oocytes for in vitro blastocyst production.

Blastocyst viability is related to the timing of blastocyst formation (Majerus et al. 2000), embryo cryotolerance assessed by blastocyst re-expansion rates post-warming (Leoni et al. 2009) and the number of blastomeres at a given age and their allocation to the inner cell mass (ICM) and the trophectoderm (TE; Papaioannou \& Ebert 1988). The blastocyst is composed of two different cell lineages: TE and the ICM. The inside cells develop into the ICM of the blastocyst and the outside cells progressively lose their pluripotency, differentiating into an extraembryonic tissue, the TE.

Mitochondria are maternally inherited organelles that use oxidative phosphorylation to supply energy (ATP) to the cell (Stojkovic et al. 2001). The distribution of mitochondria changes during oocyte maturation and fertilisation with the aim of bringing mitochondria to the region of the cell where a higher level of ATP (Van Blerkom \& Runner 1984) or calcium (Sousa et al. 1997) is required. It has been demonstrated that mitochondrial function and the cytoplasmic ATP level can affect fertilisation, resulting in a significant increase in blastocyst rates or their total failure after IVF (Van Blerkom et al. 1995, Liu et al. 2000). Mitochondrial distribution and activity are modified during oocyte in vitro maturation (IVM) and this differs among species such as cattle (Stojkovic et al. 2001, Tarazona et al. 2006), dogs (Valentini et al. 2010), goats (Velilla et al. 2006), horses (Torner et al. 2007), humans (Van Blerkom et al. 1995, 2008, Dell'Aquila et al. 2009), mice (Calarco 1995) and pigs (Torner et al. 2004, Brevini et al. 2005). Using the fluorescence probe MitoTracker Green, Sun et al. (2001) concluded that in vitro matured pig oocytes present changes in the distribution of mitochondria causing the incomplete movement of mitochondria into the inner cytoplasm affecting the cytoplasmic maturation. In our laboratory, we found differences in the distribution pattern of mitochondria between adult and prepubertal goat oocytes (Velilla et al. 2006).

Meiosis and mitosis are regulated by the activity of the maturation-promoting factor (MPF). This universal cell cycle regulator is a heterodimer protein composed of two subunits, the catalytic subunit p34 ${ }^{\text {cdc2 }}$ (serinethreonine kinase activity) and the regulatory subunit cyclin B1. The association of these two subunits is a requirement for the activation of the protein kinase activity; also the phosphorylation of $\mathrm{p} 34^{\mathrm{cdc} 2}$ on threonine 161 by the protein kinase CDC2-activation kinase (CAK) and dephosphorylation on threonine 14 and tyrosine 15 by CDC25 phosphatase is necessary. MPF activity appears just before germinal vesicle breakdown (GVBD) increasing until metaphase $\mathrm{l}$; its activity is decreased in anaphase-telophase while its maximum level is reached at metaphase II (MII). It has been shown that incompetent goat oocytes have a limited amount of cyclin B1 (Hue et al. 1997) and p34 ${ }^{\text {cdc2 }}$ (Anguita et al. 2007). MPF activity in calf and lamb oocytes were significantly lower than in cow and ewe oocytes (Ledda et al. 2001, Salamone et al. 2001), whereas (Han et al. 2010) showed in mice that the MPF activity of prepubertal oocytes was significantly higher than that of adult oocytes. In prepubertal goats, Anguita et al. (2007) showed higher MPF activity and oocyte competence to develop up to the blastocyst stage in oocytes with a diameter larger than $135 \mu \mathrm{m}$. In conclusion, MPF activity could be a useful tool in analysing differences in oocyte quality.

Competence is acquired during oocyte growth, when the synthesis and storage of proteins and RNA take place (Crozet et al. 1981, Brevini-Gandolfi \& Gandolfi 2001). The mRNA content in oocytes is affected by animal nutrition (Pisani et al. 2008), follicle diameter (Caixeta et al. 2009), IVM culture media (Salhab et al. 2011), in vivo and in vitro conditions (Wells \& Patrizio 2008) and apoptosis (Li et al. 2009). Thus, mRNA stored in oocytes could represent a valuable tool as a molecular marker for oocyte quality. In this study, we decided to analyse the expression of two genes involved in metabolism (ATPase $\mathrm{Na}^{+} / \mathrm{K}^{+}$transporting alpha 1 (ATP1A1) and cytochrome $c$ oxidase subunit 1 (COX1)) and two genes involved in the constitutive function of the cell (cytoplasmic polyadenylation-element-binding protein (CPEB) and calcium-binding protein (S100A10)).

To our knowledge, there are no reports regarding in vitro developmental competence of prepubertal sheep oocytes selected by the BCB test. The aim of this study was to evaluate the BCB test as an indirect measure of oocyte growth to select more competent lamb oocytes for IVM, IVF and embryo culture. Also, we aimed to assess oocyte diameter, mitochondrial activity and distribution assessed by MitoTracker Orange CMTMRos probe, the MPF activity and the relative mRNA expression of four maturation gene candidates by realtime PCR in BCB selected oocytes.

\section{Results}

\section{Embryo development of prepubertal sheep oocytes selected with different $B C B$ concentrations}

The percentage of $\mathrm{BCB}+$ obtained after staining with different concentrations of BCB was 19, 28, 36 and $47 \%$ for $13,26,39$ and $52 \mu \mathrm{M} \mathrm{BCB}$ respectively (Table 1 ). 
Table 1 Immature prepubertal sheep oocytes exposed at different concentrations of Brilliant Cresyl Blue (BCB).

\begin{tabular}{lccc}
\hline & & \multicolumn{2}{c}{ Oocyte classification } \\
\cline { 3 - 4 } $\begin{array}{l}\text { BCB } \\
\text { concentration }(\mu \mathrm{M})\end{array}$ & Total COC & $\mathrm{BCB}+, n(\%)$ & $\mathrm{BCB}-, n(\%)$ \\
\hline 13 & 226 & $44(19)^{\mathrm{a}, \mathrm{A}}$ & $182(81)^{\mathrm{a}, \mathrm{B}}$ \\
26 & 225 & $64(28)^{\mathrm{b}, \mathrm{A}}$ & $161(72)^{\mathrm{b}, \mathrm{B}}$ \\
39 & 234 & $85(36)^{\mathrm{b}, \mathrm{A}}$ & $149(64)^{\mathrm{b}, \mathrm{B}}$ \\
52 & 283 & $132(47)^{\mathrm{C}}$ & $151(53)^{\mathrm{C}}$ \\
\hline
\end{tabular}

Values in the same column $\left.{ }^{(\mathrm{a}, \mathrm{b}, \mathrm{c}}\right)$ or road $(\mathrm{A}, \mathrm{B})$ with different letters differ significantly (Fisher test; $P<0.05$ ).

Although staining with $13 \mu \mathrm{M}$ BCB showed a low percentage of stained oocytes $(\mathrm{BCB}+)$, the number of blastocysts obtained in this group $(21 \%)$ was significant higher $(P<0.05)$ than with $39 \mu \mathrm{M}(10 \%)$ and $52 \mu \mathrm{M}$ BCB ( $8 \%$; Table 2). Of 174 inseminated oocytes from the control group (not exposed to BCB), $116(67 \%)$ were cleavage oocytes and $14(8 \%)$ reached the blastocyst stage. This percentage of blastocysts was significantly different from $\mathrm{BCB}+$ but not from BCB - oocytes. After $24 \mathrm{~h}$ of IVM there were no significant differences in the percentage of oocytes (stained with $13 \mu \mathrm{M} \mathrm{BCB}$ ) reaching the MII stage in $\mathrm{BCB}+, \mathrm{BCB}-$ and the control group $(86,72.5$ and $80 \%$ respectively). After $17 \mathrm{~h}$ of IVF, the percentage of normal fertilisation (2PN) was significantly different $(P<0.05)$ between the $\mathrm{BCB}+(40 \%)$ and $\mathrm{BCB}-$ groups $(22 \%)$, and between $\mathrm{BCB}+$ and controls (23\%) selected with $13 \mu \mathrm{M} \mathrm{BCB}$ (Table 3 ).

The analysis of the cell number counting at day 8 postinsemination of all blastocysts produced in vitro from prepubertal sheep oocytes selected with $13 \mu \mathrm{M}$ BCB is summarised in Table 4. BCB + oocytes produced blastocysts with a significantly $(P<0.001)$ higher number of cells than BCB - oocytes, $69.71 \pm 6.19$ and 45.91 \pm 3.35 respectively. The ICM and TE cell number were higher in $\mathrm{BCB}+(18.82 \pm 1.77$ and $50.88 \pm 5.06)$ than $\mathrm{BCB}-(12.55 \pm 1.12$ and $33.36 \pm 3.16$ respectively). The ICM:TE ratio was not significant between BCB selected groups (1:2.70 and 1:2.65 respectively).

Before maturation, the mean diameter of $\mathrm{BCB}+$ oocytes was $123.66 \pm 2.72$ ( \pm s.E.M.), significantly higher $(P<0.0001)$ than BCB $-(106.82 \pm 2.88)$. After $24 \mathrm{~h}$ of IVM, the $\mathrm{BCB}+$ group maintained their diameter while
$\mathrm{BCB}$ - showed a significant increase of $12 \mu \mathrm{m}$ of the internal zona diameter (from $106.82 \pm 2.88$ to 118.86 $\pm 3.26 \mu \mathrm{m} ; P=0.006)$.

\section{Mitochondrial activity in prepubertal sheep oocytes selected by $B C B$}

Figure 1 shows representative images for the different mitochondrial distribution parameters. At the GV stage, $43.9 \%$ of oocytes presented homogeneous (Fig. 1B) and $56.1 \%$ showed peripheral (Fig. 1C) distribution. After maturation, $53.2 \%$ showed a homogeneous distribution while the peripheral distribution decreased up to $6.4 \%$, the rest of the oocytes exhibited a polarised distribution (40.4\%) marked by the position of active mitochondria around the metaphase spindle and polar body (Fig. 1D; $P<0.001)$. No differences were found in mitochondrial distribution between $\mathrm{BCB}+$ and $\mathrm{BCB}-$ oocytes.

Mitochondrial activity is represented in Fig. 2 by the analysis of the fluorescence intensity in oocytes prelabelled with the mitochondrial-specific probe. Our results indicate a relationship between mitochondrial activity, $\mathrm{BCB}$ oocyte status and maturation stage. Before IVM, BCB + and BCB - oocytes showed no significant differences in mitochondrial activity between groups $(2834 \pm 223.42$ and $3519 \pm 288.48 \mathrm{AU}$ respectively). After IVM, BCB - oocytes mitochondrial activity descended abruptly (from $3519 \pm 288.48$ to $1565 \pm 113.8 \mathrm{AU}$; $P<0.0001)$ while activity in the $\mathrm{BCB}+$ group did not show any changes. Between matured $\mathrm{BCB}+$ and $\mathrm{BCB}-$ oocytes, mitochondrial activity differed significantly $(P<0.0001)$. Considering the overall oocytes and comparing mitochondrial activity at the GV and MII stages, we observed a decreasing activity during meiosis ( $3175 \pm 253.9$ to $2385 \pm 233 \mathrm{AU} \pm$ s.E.M. respectively $P<0.05)$.

\section{MPF activity in prepubertal sheep oocytes selected by $B C B$}

Results in MPF activity of oocytes with different cytoplasmic quality and stage of maturation assessed by CDC2 kinase activity are presented in Fig. 3. No differences were observed in MPF activity at collection

Table 2 Embryo development of prepubertal sheep oocytes selected with different Brilliant Cresyl Blue (BCB) concentrations.

\begin{tabular}{|c|c|c|c|c|c|c|}
\hline \multirow[b]{3}{*}{$\begin{array}{l}\text { BCB concentration } \\
(\mu \mathrm{M})\end{array}$} & \multicolumn{6}{|c|}{ Oocyte classification } \\
\hline & \multicolumn{3}{|c|}{$\mathrm{BCB}+, n(\%)$} & \multicolumn{3}{|c|}{$\mathrm{BCB}-, n(\%)$} \\
\hline & $\begin{array}{l}\text { Inseminated } \\
\text { oocytes }\end{array}$ & Cleavage & Blastocyst & $\begin{array}{l}\text { Inseminated } \\
\text { oocytes }\end{array}$ & Cleavage & Blastocyst \\
\hline 13 & 107 & $85(79)^{\mathrm{a}}$ & $22(21)^{\mathrm{a}, \mathrm{A}}$ & 204 & $128(63)^{a, b}$ & $18(9)^{\mathrm{a}, \mathrm{B}}$ \\
\hline 26 & 114 & $77(68)^{b}$ & $19(17)^{a, c, A}$ & 192 & $122(64)^{a, b}$ & $9(5)^{\mathrm{a}, \mathrm{B}}$ \\
\hline 39 & 136 & $90(66)^{b}$ & $14(10)^{b, c}$ & 202 & $145(72)^{\mathrm{a}}$ & $13(6)^{\mathrm{a}}$ \\
\hline 52 & 123 & $86(70)^{a, b}$ & $10(8)^{b}$ & 207 & $120(58)^{b}$ & $9(4)^{a}$ \\
\hline
\end{tabular}

Values in the same column $\left(^{\mathrm{a}, \mathrm{b}, \mathrm{c}}\right)$ or row $(\mathrm{A}, \mathrm{B})$ with different letters differ significantly (Fisher test; $\left.P<0.05\right)$. 
Table 3 Nuclear stage of prepubertal sheep Brilliant Cresyl Blue (BCB) selected oocytes at $17 \mathrm{~h}$ post-insemination.

\begin{tabular}{lccccc}
\hline $\begin{array}{l}\text { Oocyte } \\
\text { classification } \\
(13 \mu \mathrm{M} \text { BCB })\end{array}$ & $\begin{array}{c}\text { Oocytes } \\
\text { at MII }(\%)\end{array}$ & $\begin{array}{c}\text { Inseminated } \\
\text { oocytes }\end{array}$ & \multicolumn{2}{l}{ Fertilised oocytes, $\boldsymbol{n}(\%)$} \\
\cline { 5 - 6 } & 80 & 68 & $16(23)^{\mathrm{b}}$ & & $2(3)$ \\
Control & 86 & 60 & $24(40)^{\mathrm{a}}$ & $3(5)$ & \\
$\mathrm{BCB}+$ & 72.5 & 64 & $14(22)^{\mathrm{b}}$ & $4(6)$ & $3(5)$ \\
$\mathrm{BCB}-$ & & 64 &
\end{tabular}

Different letters $\left({ }^{a, b}\right)$ within a column are significantly different (Fisher test; $P<0.05)$. MII, metaphase II; $2 \mathrm{PN}$, one sperm tail and 2 pronuclei; PS (polyspermic), two or more sperm tails or more than 2 pronuclei; AS (asynchronous), only one pronucleus.

time in $\mathrm{BCB}+$ and $\mathrm{BCB}-$ oocytes $(0.285 \pm 0.03$ and $0.212 \pm 0.01$ optical density (OD) respectively). After IVM, MPF showed a significantly $(P<0.05)$ increased activity in $\mathrm{BCB}+$ with respect to $\mathrm{BCB}-$ oocytes $(1.479 \pm 0.09$ and $1.184 \pm 0.05$ OD respectively). In both cases $\mathrm{BCB}+$ and $\mathrm{BCB}-$ oocytes showed a significantly $(P<0.001)$ increasing MPF activity from the GV to the MII stage of maturation.

\section{Relative mRNA expression of ATP1A1, COX1, CPEB and S100A10 of BCB selected oocytes}

Figure 4 shows the relative expression (RE) of the four maturation gene candidates analysed by real-time PCR in relation to $B C B$ status and IVM. No differences in gene expression were observed in relation to $\mathrm{BCB}$ classification. The only difference we found was in $\mathrm{BCB}+$ oocytes that showed a significantly lower amount of S100A10 transcript after IVM $(P<0.05)$.

\section{Discussion}

This study was carried out to determine the best concentration of BCB stain to select competent prepubertal sheep oocytes for in vitro embryo production and to analyse mitochondrial distribution and activity, MPF activity and changes in the RE of ATP1A1, COX1, $C P E B$ and $S 100 A 10$ as maturation gene candidates in those BCB selected oocytes.

In cows (Pujol et al. 2004, Alm et al. 2005), goats (Rodriguez-Gonzalez et al. 2002) and mice (Wu et al. 2007) the concentration of BCB stain with the best results was $26 \mu \mathrm{M}$ BCB for $90 \mathrm{~min}$, while in pigs $13 \mu \mathrm{M}$ BCB was sufficient to increase sperm penetration of $B C B+$ oocytes (Roca et al. 1998, Egerszegi et al. 2010). In our work, we decided to work with $13 \mu \mathrm{M} \mathrm{BCB}$ for 60 min, as it was the most specific concentration, increasing blastocyst rate from $9 \%(\mathrm{BCB}-)$ to $21 \%(\mathrm{BCB}+)$. We considered $B C B$ stain not to be detrimental for oocytes because no differences were found between treatments and the control group as described by Wongsrikeao et al. (2006) in pigs.

Oocyte diameter is a determinant factor for completion of meiosis and acquisition of full competence for embryo development (Lonergan et al. 1994, Crozet et al. 2000). In our work, we found that the BCB test was helpful in selecting larger oocytes with $123.66 \pm 2.72 \mu \mathrm{m}$ diameter $(\mathrm{BCB}+)$ compared with those of $106.82 \pm 2.88 \mu \mathrm{m}$ $(\mathrm{BCB}-)$. This confirmed previous reports in cattle (152.6 vs $147 \mu \mathrm{m}$; Pujol et al. 2004), goats (136.6 vs $125.5 \mu \mathrm{m}$; Rodriguez-Gonzalez et al. 2002) and pigs (113.08 vs $100.29 \mu \mathrm{m}$; Roca et al. 1998) for BCB + and $\mathrm{BCB}$ - respectively. After IVM, we found a significant increase of $12 \mu \mathrm{m}$ of the internal zona diameter in BCB oocytes, while $\mathrm{BCB}+$ oocytes maintained the same diameter after $24 \mathrm{~h}$ of in vitro culture. Oocyte quality is assessed by male pronuclear formation (2PN zygotes), blastocyst yield and blastocyst cell number. In this study, we have observed significantly higher $2 \mathrm{PN}$ zygote and blastocyst production in $\mathrm{BCB}+$ than $\mathrm{BCB}-$ oocytes. This increase in $2 \mathrm{PN}$ zygote and blastocyst development has been shown in BCB + oocytes of buffalo (Manjunatha et al. 2007), cattle (Pujol et al. 2004, Alm et al. 2005, Bhojwani et al. 2007, Torner et al. 2008), goats (Rodriguez-Gonzalez et al. 2002), mice (Wu et al. 2007) and pigs (Egerszegi et al. 2010).

Assessment of blastocyst cell number indicates that $\mathrm{BCB}+$ oocytes produce blastocysts with a higher cell number than $\mathrm{BCB}-$. In prepubertal goat oocytes, Romaguera et al. $(2010,2011)$ did not find differences in blastocyst quality, assessed by blastomere ploidy and cryotolerance, between oocytes coming from different diameter follicles and between oocytes from adult and prepubertal goats, concluding that oocyte quality was positively related to blastocyst production but not to blastocyst quality. In cattle, Majerus et al. (2000) observed that the percentage of blastocysts obtained from calf oocytes was reduced in comparison with those from adult animals (26 vs $46 \%$ ); however, the number of blastocyst cells was not different (89 and 100 respectively) and the ICM:TE ratio was similar (1:2.70 and

Table 4 Total cell numbers of in vitro produced blastocyst from prepubertal sheep Brilliant Cresyl Blue (BCB) selected oocytes at day 8 postinsemination.

\begin{tabular}{|c|c|c|c|c|c|c|c|}
\hline & \multirow[b]{2}{*}{$N$} & \multicolumn{3}{|c|}{ Cell number (mean \pm s.E.M.) } & \multicolumn{3}{|c|}{ Percentage/total cells $(n)$} \\
\hline & & Total & TE & ICM & ICM & TE & ICM:TE ratio \\
\hline $\mathrm{BCB}+$ & 24 & $\begin{array}{l}69.71 \pm 6.19^{\mathrm{a}} \\
45.91+3.35^{\mathrm{b}}\end{array}$ & $50.88 \pm 5.06^{\mathrm{a}}$ & $18.83 \pm 1.77^{\mathrm{a}}$ & 27.01 & 72.99 & $1: 2.70$ \\
\hline $\mathrm{BCB}-$ & 22 & $45.91 \pm 3.35^{\mathrm{b}}$ & $33.36 \pm 3.16^{\mathrm{b}}$ & $12.55 \pm 1.12^{\mathrm{b}}$ & 27.34 & 72.66 & $1: 2.65$ \\
\hline
\end{tabular}

ICM, inner cell mass; TE, trophectoderm. Different letters $\left(^{\mathrm{a}, \mathrm{b}}\right)$ within are significantly different (Student's $t$-test; $\left.P<0.05\right)$. 

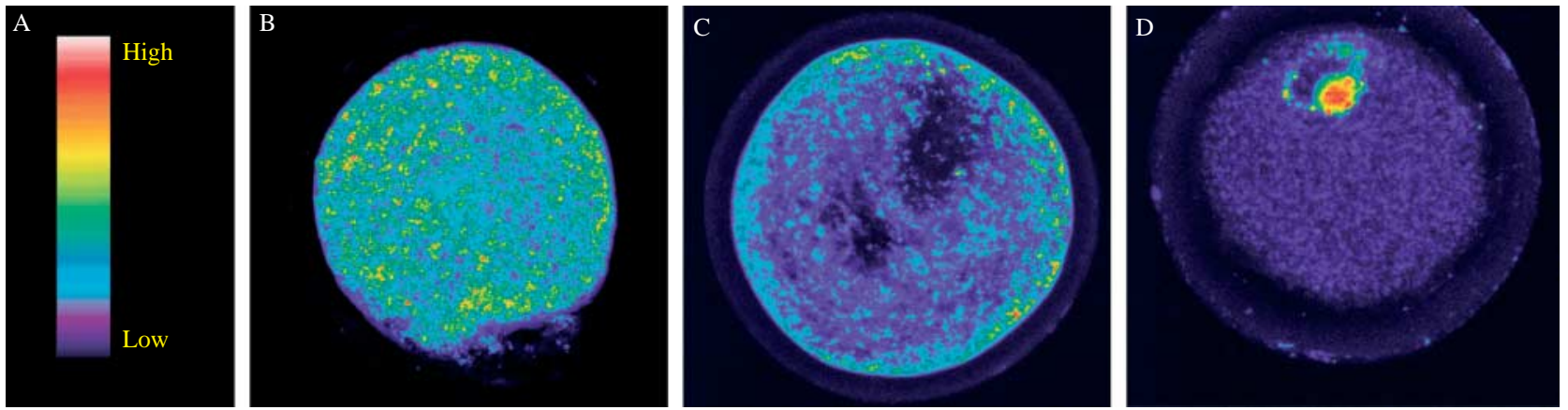

Figure 1 Representative images of active mitochondrial distribution of prepubertal sheep oocytes taken by a confocal microscope. Images were spectrally (A) coded to represent staining intensity (red is the highest intensity). Representative images of (B) homogeneous, (C) peripheral and (D) polarised mitochondrial activity distribution in lamb oocytes.

1:2.85 respectively). Selecting lamb oocytes according to the number of cumulus layers, Kelly et al. (2007) concluded that the percentage of day 8 blastocysts was affected by COC grade but the number of blastocyst cells was not significantly different (range 49.2-54.6 cells per blastocyst). To our knowledge, no studies on oocytes selected by $\mathrm{BCB}$ and embryo quality have been done. In this study, we have shown a positive relationship between $\mathrm{BCB}+$ oocytes and the number of blastomeres per blastocyst.

Mitochondrial distribution and activity inside the oocyte could be a good marker of oocyte competence to develop to the blastocyst stage. The primary function of mitochondria is to generate ATP. Van Blerkom et al. (1995) described in human oocytes the relationship between ATP content and embryo developmental capacity where a transient decrease in ATP content can lead to embryo arrest. Therefore, these data suggest that mitochondrial activity is a determinant factor of quality and changes in mitochondrial activity can alter oocyte quality in a remarkable way. In cattle (Tarazona et al. 2006), horses (Torner et al. 2007), humans (Van Blerkom 2004) and pigs (Torner et al. 2004) an increase in mitochondrial activity after IVM was described. In cattle, Torner et al. (2008) observed higher mitochondrial activity in $\mathrm{BCB}-$ oocytes than in $\mathrm{BCB}+$. These authors speculated that the reason for the increasing respiratory activity in low-quality oocytes was to provide ATP for still unfinished processes for cytoplasmic maturation. In pig oocytes, Egerszegi et al. (2010) found a higher mitochondrial activity in $\mathrm{BCB}+$ compared with $\mathrm{BCB}-$ oocytes before IVM, but after IVM, no differences were found between either kind of oocyte. They attribute this to $\mathrm{BCB}+$ oocytes increasing their respiratory activity to provide ATP for the energy-demanding processes of GVBD and the subsequent condensation of chromatin up to MII, while BCB - oocytes showed no changes in mitochondrial activity during meiosis and only a few of them reached MII stage. In our study with prepubertal sheep oocytes, we found a decrease in mitochondrial activity from the GV to the MII stage (3175 $\pm 253.9-2385 \pm 233$ AU \pm s.E.M.). Analysing BCB + and $\mathrm{BCB}$ - oocytes separately, we found that at the GV stage there were no differences in mitochondrial activity between groups. However, after IVM, BCBoocytes showed a significant reduction in mitochondrial activity while $\mathrm{BCB}+$ mitochondrial activity remained constant. This would indicate a positive relationship between mitochondrial activity at MII stage and embryo development.

Stojkovic et al. (2001) showed that mitochondrial reorganisation was different between morphologically good and poor quality oocytes. In our study, mitochondria migrated throughout the IVM process. Oocytes at the GV stage presented a homogeneous (43.9\%) or peripheral $(56.1 \%)$ mitochondrial distribution. After $24 \mathrm{~h}$ of IVM, MII oocytes presented a homogeneous $(53.2 \%)$ distribution or mitochondria polarised around the metaphase spindle and inside the polar body (PB; $40.4 \%$ ). We have previously shown (Velilla et al. 2006), in prepubertal goat IVM oocytes, that total mitochondria migrate from a cortical and perinuclear distribution in GV oocytes to a polarised distribution opposite the metaphase spindle and inside the PB (86\%) after IVM, whereas ovulated adult goat oocytes presented a mitochondrial distribution inside the PB and aggregated to the metaphase spindle (Velilla et al. 2006) as we have found here in lamb oocytes. In pigs, Torner et al. (2004)

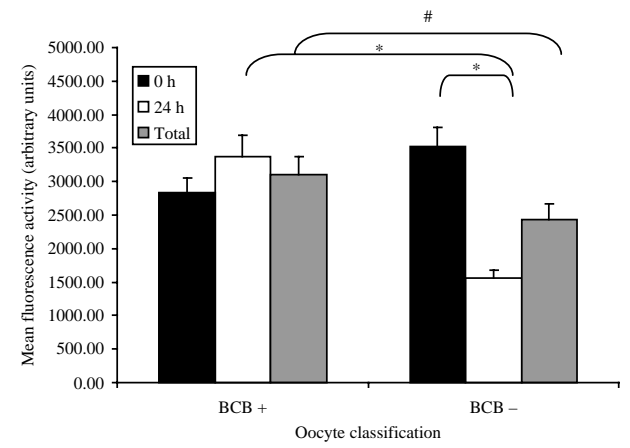

Figure 2 Mitochondrial activity of BCB selected oocytes assessed by fluorescence intensity before $(0 \mathrm{~h})$ and after IVM $(24 \mathrm{~h})$. Different symbols $\left(\#,{ }^{*}\right)$ indicate significant differences $\left({ }^{*} P<0.0001\right.$; $\left.{ }^{\#} P<0.05\right)$. 


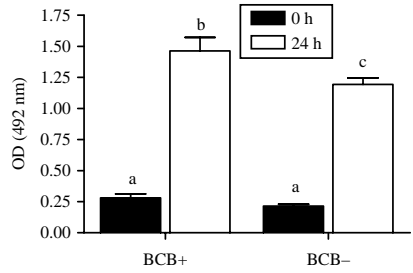

Figure 3 MPF activity in BCB-exposed prepubertal sheep oocytes before $(0 \mathrm{~h})$ and after IVM $(24 \mathrm{~h})$. MPF activity is expressed as OD at $492 \mathrm{~nm}$. ${ }^{a, b}, \mathrm{c}$ Indicates a significant difference in kinase activity among oocyte groups.

found that mitochondria moved from a homogeneous to a peripheral distribution; however, Brevini et al. (2005) showed a peripheral distribution in immature pig oocytes that became diffused after IVM. In our study, we did not find differences in mitochondrial distribution between $\mathrm{BCB}$ oocyte groups, while Egerszegi et al. (2010) concluded that, in pigs, BCB - oocytes showed more heterogeneous and non-aggregated mitochondrial distribution than BCB + oocytes. Different authors have reported differences in mitochondrial distribution patterns among species, during IVM and in vivo maturation (Stojkovic et al. 2001, Sun et al. 2001, Torner et al. 2004, Velilla et al. 2006, Torner et al. 2007, Dell'Aquila et al. 2009, Egerszegi et al. 2010).

Previous studies showed that GV-oocytes do not present MPF activity (Dedieu et al. 1996) but, in our study, we detected MPF activity before IVM; this may be due to the $\mathrm{BCB}$ staining time. We presume that oocytes could restart meiosis and so they were in GVBD instead of GV when MPF analysis took place. After IVM, we observed significantly higher MPF activity in BCB+ oocytes than in BCB - oocytes. Salamone et al. (2001) reported that calf oocytes undergo cleavage and blastocyst production at significantly lower rates than cow oocytes and this was correlated to a lower activity of MPF in these oocytes. Closer to our study, comparing prepubertal and adult sheep oocytes, Ledda et al. (2001) showed that the low competence in prepubertal oocytes could be due to morphological anomalies and alterations in physiological activity due to the evidence of low MPF activity after IVM. Bogliolo et al. (2004) showed a higher MPF activity in in vivo matured oocytes than in in vitro matured cat oocytes, suggesting a possibly incomplete cytoplasmic maturation after culture. High MPF activity was observed by Anguita et al. (2007) in oocytes with larger diameter and better competence to develop to the blastocyst stage. In addition, MPF activity has also been related to an increase in developmental competence of oocytes treated with caffeine during nuclear transfer (Kawahara et al. 2005). In relation to mitochondrial and MPF activities analysed in this work, we could speculate that there is a positive relationship between the ATP produced by the active mitochondria and the ATP production needed to phosphorylate p34 ${ }^{\text {cdc2 }}$ and activate the MPF complex.
The genes analysed in this work were related to metabolism (ATP1A1 and COX1) and constitutive function of the cell (CPEB and S100A10). Oocytes selected by BCB did not show any differences in RE in any of the studied genes, in spite of the higher embryo development observed in BCB + oocytes. However, in bovine oocytes, Opiela et al. (2010) found higher RE of the $C O X 1$ gene in immature $\mathrm{BCB}+$ with respect to BCB - and Torner et al. (2008) showed a higher RE of S100A 10 in matured BCB - than BCB + oocytes. During IVM in prepubertal sheep oocytes, we found a significant decreasing mRNA RE in S100A10 in BCB + oocytes.

In conclusion, exposing prepubertal sheep oocytes to $13 \mu \mathrm{M} \mathrm{BCB}$ for $60 \mathrm{~min}$ stains the largest and most competent oocytes to develop to the blastocyst stage. After IVM, the more competent oocytes $(B C B+)$ presented higher mitochondrial and MPF activity with respect to $\mathrm{BCB}-$ oocytes. $\mathrm{BCB}+$ oocytes produced blastocysts with higher numbers of cells than $\mathrm{BCB}-$ oocytes. Mitochondrial distribution and mRNA expression of ATP1A1, COX1, CPEB and S100A10 were not affected by oocyte quality.

\section{Materials and Methods}

\section{Chemical}

All chemicals were purchased from Sigma-Aldrich Chemical Co. unless otherwise specified.

\section{Oocyte collection}

Ovaries from prepubertal ewes (3-6 months old), were obtained from a local abattoir and transported to laboratory in sterile dulbecco's (PBS) held at $34-37^{\circ} \mathrm{C}$ and were washed
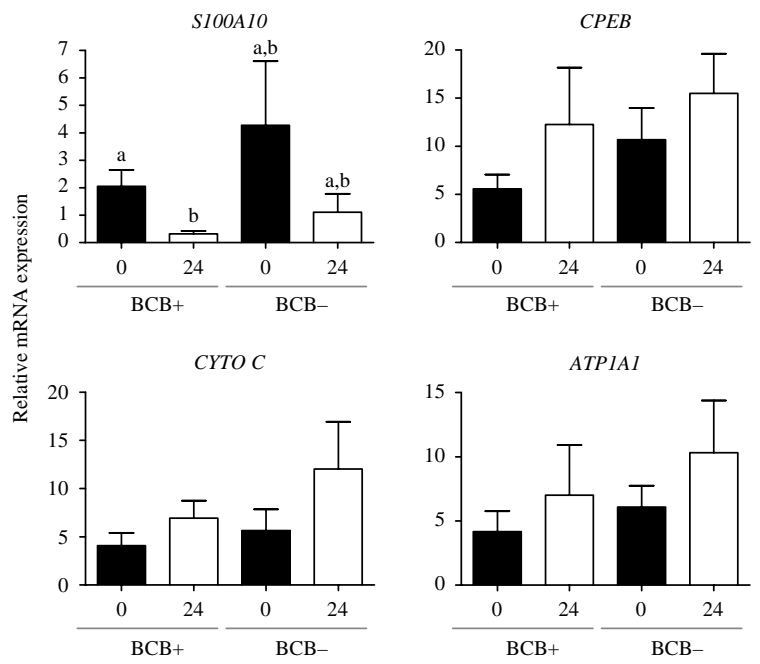

Figure 4 Relative mRNA expression of S100A10, CPEB, COX1 and ATP1A1 transcripts before $(0 \mathrm{~h})$ and after IVM $(24 \mathrm{~h})$ of prepubertal sheep BCB selected oocytes. Different letters $(a, b)$ indicate significant differences $(P<0.05$ : one-way ANOVA with Tukey's multiple comparison post-test to compare the four groups of each gene). 
in PBS containing antibiotic-antimycotic $(A B$, Gibco cat no. 14240-062). COCs were recovered by slicing the surface of the ovary in HEPES-buffered TCM-199 medium with $0.5 \mathrm{~g} / \mathrm{l}$ fraction $\mathrm{V}$ BSA. Oocytes with two or more complete layers of compact cumulus cells and homogeneous cytoplasm were used.

\section{BCB test}

Immediately after collection, COCs were washed three times in mPBS (PBS supplemented with $1 \mathrm{~g} / \mathrm{l}$ glucose, $36 \mathrm{mg} / \mathrm{l}$ sodium pyruvate, $0.5 \mathrm{~g} / \mathrm{l} \mathrm{BSA}$ and $0.05 \mathrm{~g} / \mathrm{l}$ gentamicin) and exposed to different concentrations of $\mathrm{BCB}(13,26,39$ and $52 \mu \mathrm{M})$ diluted in $\mathrm{mPBS}$ for $1 \mathrm{~h}$ at $38.5^{\circ} \mathrm{C}$ in a humidified air atmosphere. After BCB incubation, oocytes were washed three times in mPBS and classified into two groups depending on their cytoplasm colouration: oocytes with blue cytoplasm or hypothetically grown oocytes $(\mathrm{BCB}+)$ and oocytes without blue cytoplasm colouration or hypothetically growing oocytes (BCB-).

\section{IVM of oocytes}

Groups of 35-40 COCs of BCB +, BCB - and control (oocytes not exposed to BCB stain), were washed and cultured for $24 \mathrm{~h}$ at $38.5^{\circ} \mathrm{C}$ in a humidified air atmosphere with $5 \% \mathrm{CO}_{2}$ in $500 \mu \mathrm{l}$ of maturation medium covered with mineral oil. Maturation medium consisted of TCM-199 supplemented with $5 \mu \mathrm{g} / \mathrm{ml} \mathrm{LH}, 5 \mu \mathrm{g} / \mathrm{ml} \mathrm{FSH}, 1 \mu \mathrm{g} / \mathrm{ml} 17 \beta$ oestradiol, $10 \mathrm{ng} / \mathrm{ml}$ epidermal growth factor, $0.2 \mathrm{mM}$ sodium pyruvate, $2 \mathrm{mM}$ glutamine, $100 \mu \mathrm{M}$ cysteamine, $10 \%(\mathrm{v} / \mathrm{v})$ fetal bovine serum (FBS) and $\%(\mathrm{v} / \mathrm{v}) \mathrm{AB}$.

\section{IVF and embryo culture}

Fresh semen, obtained from three rams of proven fertility, was kept at room temperature $\left(25^{\circ} \mathrm{C}\right)$ for 90 min (Ptak et al. 1999). Highly motile spermatozoa were selected by Ovipure density gradient (Nidacon EVB S.L., Barcelona, Spain) and fertilised with $1 \times 10^{6}$ spermatozoa/ml. Matured oocytes were partially denuded by gentle pipetting and transferred into fertilisation medium consisting of synthetic oviductal fluid (SOF; Holm et al. 1999). Fertilisation was carried out in drops of $50 \mu \mathrm{l}$ of SOF medium supplemented with $10 \%$ of oestrous sheep serum with a maximum of 15 oocytes per drop and incubated for $20 \mathrm{~h}$ at $38.5{ }^{\circ} \mathrm{C}, 5 \% \mathrm{CO}_{2}$ and $5 \% \mathrm{O}_{2}$ in a humidified atmosphere.

After IVF, presumptive zygotes were completely denuded with gently pipetting and cultured in groups of six zygotes for 8 days in $20 \mu \mathrm{l}$ culture drops consisting of SOF medium supplemented with $10 \%(\mathrm{v} / \mathrm{v})$ FBS under the same atmospheric conditions.

\section{Blastocyst differential staining}

Blastocyst differential stain protocol was taken and modified from Thouas (2001). Briefly, 8-day-old blastocysts were first incubated for $\sim 15 \mathrm{~s}$ or until TE visibly changed colour in solution 1 (PBS-BSA free with 1\% Triton X-100 and $100 \mu \mathrm{g} / \mathrm{ml}$ propidium iodide). Immediately afterwards they were transferred to solution $2(100 \%$ ethanol with $25 \mu \mathrm{g} / \mathrm{ml}$ Hoechst 33258) for $1 \mathrm{~h}$.

Stained blastocysts were transferred from solution 2 directly to a glass with a drop of glycerol, taking care to avoid carrying over an excessive amount of solution, flattened with a coverslip and visualised under a microscope for cell counting. We used an Olympus BX50 with a u.v. lamp and excitation filter of $460 \mathrm{~nm}$ for blue and red fluorescence.

The intense pink colour represents the chromatin in nuclei of permeabilised TE cells that are stained both red (propidium iodide) and blue (Hoechst). ICM nuclei remain blue, because these cells have not been permeabilised.

\section{Oocyte diameter and nuclear stage of $13 \mu \mathrm{M} \mathrm{BCB}$ selected oocytes}

Oocyte diameter was measured after selection by the BCB test $(0 \mathrm{~h})$ and after IVM $(24 \mathrm{~h})$. Oocytes were denuded and fixed with $3 \%$ paraformaldehyde and mounted on poly-L-lysinetreated coverslips fitted with a self-adhesive reinforcement ring and then covered with a drop of Vectashield Mounting Medium (Vector Laboratories, Inc., Burlingame, CA, USA). Oocytes were measured (inside zona pellucida) by taking a picture under the microscope and analysed with MetaMorph imaging software (MetaMorph 6.2.6 Software, Universal Imaging Corporation).

To evaluate the nuclear and pronuclear stages, maturated and fertilised (after $17 \mathrm{~h}$ of IVF) COCs were denuded as described before and fixed during $24 \mathrm{~h}$ in ethanol: acetic $(3: 1)$ and stained it with $1 \%$ lacmoid. Oocytes were considered correctly matured when they reached the MII stage and correctly fertilised when one sperm tail and 2 pronuclei (2PN) were visible, polyspermic when two or more sperm tails or more than 2 pronuclei (PS) were visible and asynchronous when only one pronucleus and a non-decondensed sperm were present.

\section{Mitochondrial activity of BCB selected oocytes}

Prepubertal sheep oocytes selected with $13 \mu \mathrm{M}$ BCB at 0 and 24 h post IVM were totally denuded with gentle pipetting and incubated in mPBS with $3 \%(\mathrm{v} / \mathrm{v})$ BSA containing 200 nM MitoTracker Orange CMTMRos (Molecular Probes, Inc., Eugene, OR, USA) under culture conditions for $60 \mathrm{~min}$. The probe is readily sequestered only by active organelles depending on their oxidative activity. Immediately after staining, oocytes were washed three times in mPBS and fixed for $60 \mathrm{~min}$ at $38{ }^{\circ} \mathrm{C}$ in $3 \%$ paraformaldehyde. After fixation, oocytes were properly washed in PBS $0.1 \%(\mathrm{v} / \mathrm{v}) \mathrm{BSA}$ and stained for $5 \mathrm{~min}$ in $1 \mu \mathrm{g} / \mathrm{ml}$ Hoechst 33342 solution. Finally, groups of ten oocytes were mounted on poly-L-lysine-treated coverslips fitted with a self-adhesive reinforcement ring and covered with a drop of Vectashield mounting medium. Slides were then sealed with nail varnish and stored at $-20{ }^{\circ} \mathrm{C}$ protected from light for 6 days until their analysis under a confocal microscope. 


\section{Confocal analysis}

A laser scanning confocal microscope (Espectral Leica TCSSP5, Mannheim, Germany) was used to examine active mitochondria (MitoTracker Orange CMTMRos, excitation $554 \mathrm{~nm}$ ) and chromatin (Hoechst; excitation $405 \mathrm{~nm}$ ). The mitochondrial distribution pattern (representative images in Fig. 1) was characterised with $60 \times$ magnification under mineral oil and classified as homogeneous (fluorescence throughout the cytoplasm, Fig. 1B), peripheral (fluorescence in the cortex, Fig. 1C) or polarised (fluorescence near the MII spindle, Fig. 1D) according to mitochondrial distribution.

For mitochondrial intensity the microscope objective, pinhole, filters, offset, gain, pixels and laser potency were kept constant throughout the experiment. Twenty serial cuts of $1 \mu \mathrm{m}$ each in the region of major intensity were performed. The 20 images of each oocyte were added in a unique picture and analysed with MetaMorph imaging software. To express the fluorescence intensity, we used arbitrary unit of the mean fluorescence intensity, which is defined as the sum of fluorescence intensity in greyscale of every pixel in the cytoplasm of the oocyte divided by the sum of all pixels of the same region.

\section{MPF activity of $B C B$ selected oocytes}

Before and after IVM, groups of 20 oocytes $\mathrm{BCB}+, \mathrm{BCB}-$ (three replicates) were washed three times in PBS, and placed in tubes containing $5 \mu \mathrm{l}$ of lysis buffer $(50 \mathrm{mM}$ Tris- $\mathrm{HCl}, \mathrm{pH} 7.5$, $0.5 \mathrm{M} \mathrm{NaCl}, 5 \mathrm{mM}$ EDTA, $0.01 \%$ Brij35, $1 \mathrm{mM}$ PMSF, $0.05 \mathrm{mg} / \mathrm{ml}$ leupeptin, $50 \mathrm{mM}$ 2-mercaptoethanol, $25 \mathrm{mM}$ $\beta$-glycerophosphate and $1 \mathrm{mM}$ Na-orthovanadate). The samples were frozen in liquid nitrogen and sonicated three times at $1{ }^{\circ} \mathrm{C}$ for $25 \mathrm{~s}$. Cell extracts were stored at $-80^{\circ} \mathrm{C}$ until use.

CDC2 assay was performed by the MESACUP CDC2 kinase assay kit (MBL, Madrid, Spain) following the manufacturer's protocol. Oocyte extracts $(5 \mu \mathrm{l})$ were mixed with $10 \times \mathrm{CDC} 2$ Reaction Buffer (25 mM Hepes buffer pH 7.5 and $10 \mathrm{mM}$ $\mathrm{MgCl} 2$ ) and $10 \%$ biotinylated MV Peptide (SLYSSPGGAYC). The phosphorylation reaction was started adding $0.1 \mathrm{mM}$ ATP (Sigma-Aldrich), in a final volume of $50 \mu \mathrm{l}$. The mixture was incubated at $30{ }^{\circ} \mathrm{C}$ for $30 \mathrm{~min}$. The reaction was finished by adding $200 \mu \mathrm{l}$ of phosphorylation Stop Reagent (PBS containing $50 \mathrm{mM}$ EGTA). The phosphorylated MV peptide was detected by ELISA at $492 \mathrm{~nm}$ and expressed as OD.

\section{Real-time PCR quantification of ATP1A1, COX1, CPEB and S100A10 of BCB selected oocytes}

Groups of 15 denuded prepubertal sheep oocytes (four replicates) stained with $13 \mu \mathrm{M} \mathrm{BCB}$ were taken at 0 and $24 \mathrm{~h}$ post IVM and stored at $-80^{\circ} \mathrm{C}$ in $100 \mu$ Trizol (Invitrogen) until use. For RNA extraction, the addition of a known amount of luciferase $(0.2 \mathrm{pg} / \mu \mathrm{l}$, Promega) was added as an exogenous standard. To avoid contamination with genomic DNA, total RNA preparations were incubated during 10 min with RQ1 DNase (Promega) as described in the manufacturer's protocol. Reverse transcription was performed by extended cDNA using Oligo (dT) 15 primers during $5 \mathrm{~min}$ at $70^{\circ} \mathrm{C}$ and $1 \mathrm{~h}$ at $65^{\circ} \mathrm{C}$ using superscript III (200 U/ $\mu \mathrm{M}$; Invitrogen). Relative qualitative PCR analysis was performed in MyiQ apparatus (Bio-Rad Laboratories). Samples were distributed in the plate by a robotic distributor (Eppendorf) and reactions were performed in duplicate using SYBR Green Fluorophore kit (Bio-Rad). Reactions were performed in $20 \mu \mathrm{l}$ final volume (in duplicate) and PCR cycling conditions were $95^{\circ} \mathrm{C}$ for $3 \mathrm{~min}$ followed by 40 cycles of denaturing $\left(30 \mathrm{~s}, 95^{\circ} \mathrm{C}\right)$, annealing $\left(30 \mathrm{~s}, 60^{\circ} \mathrm{C}\right)$ and elongation $\left(20 \mathrm{~s}, 72^{\circ} \mathrm{C}\right)$. The specificity of each PCR product was determined by a melting curve analysis and the amplicon size determination in agarose gels. For each gene, a standard curve was included, consisting of corresponding plasmid DNA fragments from $1 \mathrm{pg}$ to $0.1 \mathrm{fg}$, purified with QIAquick PCR Purification Kit (Qiagen). Correlation coefficients and PCR efficiencies were considered between 85 and $100 \%$. Primer sequences are listed in Table 5. The results for mRNA were normalised according to the relative concentration of the internal standard, luciferase and $18 \mathrm{~S}$.

\section{Statistical analysis}

Analysis among treatments (BCB stain, IVM and IVF) were performed by Fisher's exact test. Blastocyst cell numbers were analysed by Student's $t$-test. Gene and MPF analysis was performed by one-way ANOVA in GraphPad Prism v 3 (GraphPad Software, San Diego, CA, USA).

Table 5 Oligonucleotide primer sequences used in this study.

\begin{tabular}{|c|c|c|c|c|}
\hline Gene & Primer & Sequence $5^{\prime}-3^{\prime}$ & GenBank accession no. & Product size $(b p)$ \\
\hline \multirow[t]{2}{*}{ S100A10 } & Sense & CCGCCAAGGTTTCAACAGACTTC & EE822394 & 271 \\
\hline & Antisense & ATGGTGAGCCCAGCGATTAGC & & \\
\hline \multirow[t]{2}{*}{ CPEB } & Sense & ССТСССАGАТGСАААТGАСТ & DY514003 & 235 \\
\hline & Antisense & CTTAATGGAGGGTGCTGGAA & & \\
\hline \multirow{2}{*}{ COX1 } & Sense & TGGAGGACAATATCAAGGGAGGAG & CO000988 & 471 \\
\hline & Antisense & GGACCGAAACCTGAACACAACC & & \\
\hline \multirow[t]{2}{*}{ ATP1A1 } & Sense & GAACGGCTTCСТСССТАATC & NM_001009360 & 207 \\
\hline & Antisense & ACGGAATTCCTCCTGGTCTT & & \\
\hline \multirow[t]{2}{*}{$\mathrm{LUCl}$} & Sense & TCATTCTTCGCCAAAAGCACTC & & 140 \\
\hline & Antisense & AGCCСАTATCCTTGTCGTATCC & & \\
\hline \multirow[t]{2}{*}{$18 S$} & Sense & AGAAACGGCTACCACATCCAA & DQ222453.1 & 90 \\
\hline & Antisense & CCTGTATTGTTATTTTTCGT & & \\
\hline
\end{tabular}


The individual mitochondrial intensity (arbitrary unit) data were analysed as $\log 10$ to normalise them. Statistical analysis was conducted by PROC MIXED (with number of treatments as random parameter) of SAS (version 9.2 Inst.), Inc., Cary, NC, USA) according to Tukey's multiple comparison test. The statistical model contained the fixed effects of BCB (+ versus - ) and maturation state (0 vs $24 \mathrm{~h}$ ) and first-order interaction between $\mathrm{BCB}$ and maturation state and residual error. Differences were declared significant at $P<0.05$.

\section{Declaration of interest}

The authors declare that there is no conflict of interest that could be perceived as prejudicing the impartiality of the research reported.

\section{Funding}

This study was supported by grants from the Spanish Ministry of Education and Science (project number: AGL2007$60227 / \mathrm{GAN}$ ) and from the Universitat Autònoma de Barcelona (2007-FPI00193).

\section{Acknowledgements}

The authors thank Ph.D. Maria Rodriguez Prado for her statistical assistance.

\section{References}

Alm H, Torner H, Lochrke B, Viergutz T, Ghoneim IM \& Kanitz W 2005 Bovine blastocyst development rate in vitro is influenced by selection of oocytes by brillant cresyl blue staining before IVM as indicator for glucose-6-phosphate dehydrogenase activity. Theriogenology 63 2194-2205. (doi:10.1016/j.theriogenology.2004.09.050)

Anguita B, Jimenez-Macedo AR, Izquierdo D, Mogas T \& Paramio MT 2007 Effect of oocyte diameter on meiotic competence, embryo development, p34 (cdc2) expression and MPF activity in prepubertal goat oocytes. Theriogenology 67 526-536. (doi:10.1016/j.theriogenology.2006.09.003)

Armstrong DT 2001 Effects of maternal age on oocyte developmental competence. Theriogenology 55 1303-1322. (doi:10.1016/S0093-691X (01)00484-8)

Barnes FL \& Sirard MA 2000 Oocyte maturation. Seminars in Reproductive Medicine 18 123-131. (doi:10.1055/s-2000-12551)

Bhojwani S, Alm H, Torner H, Kanitz W \& Poehland R 2007 Selection of developmentally competent oocytes through Brilliant Cresyl Blue stain enhances blastocyst development rate after bovine nuclear transfer. Theriogenology 67 341-345. (doi:10.1016/j.theriogenology.2006.08.006)

Bogliolo L, Leoni G, Ledda S, Zedda MT, Bonelli P, Madau L, Santucciu C, Naitana S \& Pau S 2004 M-phase promoting factor (MPF) and mitogen activated protein kinases (MAPK) activities of domestic cat oocytes matured in vitro and in vivo. Cloning and Stem Cells 6 15-23. (doi:10. 1089/15362300460743790)

Brevini TA, Vassena R, Francisci C \& Gandolfi F 2005 Role of adenosine triphosphate, active mitochondria, and microtubules in the acquisition of developmental competence of parthenogenetically activated pig oocytes. Biology of Reproduction 72 1218-1223. (doi:10.1095/biolreprod.104.038141)

Brevini-Gandolfi TAL \& Gandolfi F 2001 The maternal legacy to the embryo: cytoplasmic components and their effects on early development. Theriogenology 55 1255-1276. (doi:10.1016/S0093-691X(01) 00481-2)

Caixeta ES, Ripamonte P, Franco MM, Buratini J \& Dode MAN 2009 Effect of follicle size on mRNA expression in cumulus cells and oocytes of
Bos indicus: an approach to identify marker genes for developmental competence. Reproduction, Fertility, and Development 21 655-664. (doi:10.1071/RD08201)

Calarco PG 1995 Polarization of mitochondria in the unfertilized mouse oocyte. Developmental Genetics 16 36-43. (doi:10.1002/dvg. 1020160108)

Cognie Y, Baril G, Poulin N \& Mermillod P 2003 Current status of embryo technologies in sheep and goat. Theriogenology 59 171-188. (doi:10.1016/S0093-691X(02)01270-0)

Crozet N, Motlij J \& Szollosi D 1981 Nucleolar fine-structure and RNAsynthesis in porcine oocytes during the early stages of antrum formation. Biology of the Cell 41 35-41.

Crozet N, Dahirel M \& Gall L 2000 Meiotic competence of in vitro grown goat oocytes. Journal of Reproduction and Fertility 118 367-373. (doi:10.1530/reprod/118.2.367)

Dedieu T, Gall L, Crozet N, Sevellec C \& Ruffini S 1996 Mitogen-activated protein kinase activity during goat oocyte maturation and the acquisition of meiotic competence. Molecular Reproduction and Development 45 351-358. (doi:10.1002/(SICl)1098-2795(199611) 45:3<351::AID-MRD12>3.0.CO;2-1)

Dell'Aquila ME, Ambruosi B, De Santis T \& Cho YS 2009 Mitochondrial distribution and activity in human mature oocytes: gonadotropinreleasing hormone agonist versus antagonist for pituitary downregulation. Fertility and Sterility 91 249-255. (doi:10.1016/j.fertnstert. 2007.10.042)

Egerszegi I, Alm H, Ratky J, Heleil B, Bruessow K-P \& Torner H 2010 Meiotic progression, mitochondrial features and fertilisation characteristics of porcine oocytes with different G6PDH activities. Reproduction, Fertility, and Development 22 830-838. (doi:10.1071/RD09140)

Gilchrist RB, Nayudu PL, Nowshari MA \& Hodges JK 1995 Meiotic competence of marmoset monkey oocytes is related to follicle size and oocyte-somatic cell associations. Biology of Reproduction $\mathbf{5 2}$ 1234-1243. (doi:10.1095/biolreprod52.6.1234)

Han D, Cao X, Wang H, Li J, Wang Y \& Tan J 2010 Effects of puberty and gonadotropins on the molecular events controlling meiotic resumption of mouse oocytes. Reproduction 139 959-969. (doi:10. 1530/REP-09-0485)

Holm P, Booth PJ, Schmidt MH, Greve T \& Callesen H 1999 High bovine blastocyst development in a static in vitro production system using sofa medium supplemented with sodium citrate and myo-inositol with or without serum-proteins. Theriogenology 52 683-700. (doi:10.1016/ S0093-691X(99)00162-4)

Hue I, Thierry D, Huneau D, Ruffini S, Gall L \& Crozet N 1997 Cyclin B-1 expression in meiotically competent and incompetent goat oocytes. Molecular Reproduction and Development 47 222. (doi:10.1002/ (SICI) 1098-2795(199706)47:2 <222::AID-MRD14>3.0.CO;2-1)

Jimenez-Macedo AR, Paramio MT, Anguita B, Morato R, Romaguera R, Mogas T \& Izquierdo D 2007 Effect of ICSI and embryo biopsy on embryo development and apoptosis according to oocyte diameter in prepubertal goats. Theriogenology 67 1399-1408. (doi:10.1016/j. theriogenology.2007.03.003)

Kawahara M, Wakai T, Yamanaka K, Kobayashi J, Sugimura S, Shimizu T, Matsumoto H, Kim J, Sasada H \& Sato E 2005 Caffeine promotes premature chromosome condensation formation and in vitro development in porcine reconstructed embryos via a high level of maturation promoting factor activity during nuclear transfer. Reproduction $\mathbf{1 3 0}$ 351-357. (doi:10.1530/rep.1.00644)

Kelly JM, Kleemann DO, Rudiger SR \& Walker SK 2007 Effects of grade of oocyte-cumulus complex and the interactions between grades on the production of blastocysts in the cow, ewe and lamb. Reproduction in Domestic Animals 42 577-582. (doi:10.1111/j.1439-0531.2006.00823.x)

Ledda S, Bogliolo L, Leoni G \& Naitana S 2001 Cell coupling and maturation-promoting factor activity in in vitro-matured prepubertal and adult sheep oocytes. Biology of Reproduction 65 247-252. (doi:10.1095/ biolreprod65.1.247)

Leoni G, Succu S, Satta V, Paolo M, Bogliolo L, Bebbere D, Spezzigo A, Madeddu M, Berlinguer F, Ledda S et al. 2009 In vitro production and cryotolerance of prepubertal and adult goat blastocysts obtained from oocytes collected by laparoscopic oocyte-pick-up (LOPU) after FSH treatment. Reproduction, Fertility, and Development 21 901-908. (doi:10.1071/RD09015) 
Li J, Liu DJ, Cang M, Wang LM, Jin MZ, Ma YZ \& Shorgan B 2009 Early apoptosis is associated with improved developmental potential in bovine oocytes. Animal Reproduction Science 114 89-98. (doi:10.1016/j. anireprosci.2008.09.018)

Liu L, Trimarchi JR \& Keefe DL 2000 Involvement of mitochondria in oxidative stress-induced cell death in mouse zygotes. Biology of Reproduction 62 1745-1753. (doi:10.1095/biolreprod62.6.1745)

Lonergan P, Monaghan P, Rizos D, Boland MP \& Gordon I 1994 Effect of follicle size on bovine oocyte quality and developmental competence following maturation, fertilization, and culture in-vitro. Molecular Reproduction and Development 37 48-53. (doi:10.1002/mrd. 1080370107)

Majerus V, Lequarré A, Ferguson EM, Kaidi S, Massip A, Dessy F \& Donnay I 2000 Characterization of embryos derived from calf oocytes: kinetics of cleavage, cell allocation to inner cell mass, and trophectoderm and lipid metabolism. Molecular Reproduction and Development 57 346-352. (doi:10.1002/1098-2795(200012)57:4< 346::AID-MRD6 > 3.0.CO;2-M)

Manjunatha BM, Gupta PSP, Devaraj M, Ravindra JP \& Nandi S 2007 Selection of developmentally competent buffalo oocytes by Brilliant Cresyl Blue staining before IVM. Theriogenology 68 1299-1304. (doi:10. 1016/j.theriogenology.2007.08.031)

Martino A, Palomo MJ, Mogas T \& Paramio MT 1994 Influence of the collection technique of prepubertal goat oocytes on in vitro maturation and fertilization. Theriogenology 42 859-873. (doi:10.1016/0093691X(94)90454-Q)

O'Brien JK, Dwarte D, Ryan JP, Maxwell WM \& Evans G 1996 Developmental capacity, energy metabolism and ultrastructure of mature oocytes from prepubertal and adult sheep. Reproduction, Fertility, and Development 7 1029-1037. (doi:10.1071/RD9961029)

Opiela J, Lipinski D, Slomski R \& Katska-Ksiazkiewicz L 2010 Transcript expression of mitochondria related genes is correlated with bovine oocyte selection by BCB test. Animal Reproduction Science $\mathbf{1 1 8}$ 188-193. (doi:10.1016/j.anireprosci.2009.07.007)

Papaioannou VE \& Ebert KM 1988 The preimplantation pig embryo: cell number and allocation to trophectoderm and inner cell mass of the blastocyst in vivo and in vitro. Development 102 793-803.

Peters JK, Milliken G \& Davis DL 2001 Development of porcine embryos in vitro: effects of culture medium and donor age. Journal of Animal Science 79 1578-1583.

Pisani LF, Antonini S, Pocar P, Ferrari S, Brevini TA, Rhind SM \& Gandolfi F 2008 Effects of pre-mating nutrition on mRNA levels of developmentally relevant genes in sheep oocytes and granulosa cells. Reproduction $\mathbf{1 3 6}$ 303-312. (doi:10.1530/REP-07-0394)

Ptak G, Loi P, Dattena M, Tischner M \& Cappai P 1999 Offspring from onemonth-old lambs: studies on the developmental capability of prepubertal oocytes. Biology of Reproduction 61 1568-1574. (doi:10.1095/biolreprod61.6.1568)

Pujol M, Lopez-Bejar M \& Paramio MT 2004 Developmental competence of heifer oocytes selected using the Brilliant Cresyl Blue (BCB) test. Theriogenology 61 735-744. (doi:10.1016/S0093-691X(03)00250-4)

Revel F, Mermillod P, Peynot N, Renard JP \& Heyman Y 1995 Low developmental capacity of in vitro matured and fertilized oocytes from calves compared with that of cows. Journal of Reproduction and Fertility 103 115-120. (doi:10.1530/jrf.0.1030115)

Rizos D, Ward F, Duffy P, Boland MP \& Lonergan P 2002 Consequences of bovine oocyte maturation, fertilization or early embryo development in vitro versus in vivo: implications for blastocyst yield and blastocyst quality. Molecular Reproduction and Development 61 234-248. (doi:10. 1002/mrd.1153)

Roca J, Martinez E, Vazquez JM \& Lucas X 1998 Selection of immature pig oocytes for homologous in vitro penetration assays with the Brilliant Cresyl Blue test. Reproduction, Fertility, and Development 6 479-485. (doi:10.1071/RD98060)

Rodriguez-Gonzalez E, Lopez-Bejar M, Velilla E \& Paramio MT 2002 Selection of prepubertal goat oocytes using the Brilliant Cresyl Blue test. Theriogenology 57 1397-1409. (doi:10.1016/S0093-691X(02)00 645-3)

Romaguera R, Casanovas A, Morató R, Izquierdo D, Catalá M, JimenezMacedo AR, Mogas T \& Paramio MT 2010 Effect of follicle diameter on oocyte apoptosis, embryo development and chromosomal ploidy in prepubertal goats. Theriogenology 74 364-373. (doi:10.1016/j.theriogenology.2010.02.019)

Romaguera R, Moll X, Morató R, Roura M, Palomo MJ, Catalá MG, Jiménez-Macedo AR, Hammami S, Izquierdo D, Mogas T et al. 2011 Prepubertal goat oocytes from large follicles result in similar blastocyst production and embryo ploidy than those from adult goats. Theriogenology 76 1-11. (doi:10.1016/j.theriogenology.2010.12.014)

Salamone DF, Damiani P, Fissore RA, Roble JM \& Duby RT 2001 Biochemical and developmental evidence that ooplasmic maturation of prepubertal bovine oocytes is compromised. Biology of Reproduction 64 1761-1768. (doi:10.1095/biolreprod64.6.1761)

Salhab M, Tosca L, Cabau C, Papillier P, Perreau C, Dupont J, Mermillod P \& Uzbekova S 2011 Kinetics of gene expression and signaling in bovine cumulus cells throughout IVM in different mediums in relation to oocyte developmental competence, cumulus apoptosis and progesterone secretion. Theriogenology 1 90-104. (doi:10.1016/j.theriogenology.2010. 07.014)

Sousa M, Barros A, Silva J \& Tesarik J 1997 Developmental changes in calcium content of ultrastructurally distinct subcellular compartments of preimplantation human embryos. Molecular Human Reproduction 3 83-90. (doi:10.1093/molehr/3.2.83)

Stojkovic M, Machado SA, Stojkovic P, Zakhartchenko V, Hutzler P, Gonçalves PB \& Wolf E 2001 Mitochondrial distribution and adenosine triphosphate content of bovine oocytes before and after in vitro maturation: correlation with morphological criteria and developmental capacity after in vitro fertilization and culture. Biology of Reproduction 64 904-909. (doi:10.1095/biolreprod64.3.904)

Sun QY, Wu GM, Lai L, Park KW, Cabot R, Cheong HT, Day BN, Prather RS \& Schatten H 2001 Translocation of active mitochondria during pig oocyte maturation, fertilization and early embryo development in vitro. Reproduction 122 155-163. (doi:10.1530/rep.0.1220155)

Tarazona AM, Rodriguez JI, Restrepo LF \& Olivera-Angel M 2006 Mitochondrial activity, distribution and segregation in bovine oocytes and in embryos produced in vitro. Reproduction in Domestic Animals 41 5-11. (doi:10.1111/j.1439-0531.2006.00615.x)

Thouas G 2001 Simplified technique for differential staining of inner cell mass and trophectoderm cells of mouse and bovine blastocyst. Reproductive Biomedicine Online 3 25-29. (doi:10.1016/S1472-6483 (10)61960-8)

Torner H, Bruessow K-P, Alm H, Ratky J, Poehland R, Tuchscherer A \& Kanitz W 2004 Mitochondrial aggregation patterns and activity in porcine oocytes and apoptosis in surrounding cumulus cells depends on the stage of pre-ovulatory maturation. Theriogenology 61 1675-1689. (doi:10.1016/j.theriogenology.2003.09.013)

Torner H, Alm H, Kanitz W, Goellnitz K, Becker F, Poehland R, Bruessow K-P \& Tuchscherer A 2007 Effect of initial cumulus morphology on meiotic dynamic and status of mitochondria in horse oocytes during IVM. Reproduction in Domestic Animals 42 176-183. (doi:10.1111/j.1439-0531.2006.00749.x)

Torner H, Ghanem N, Ambros C, Holker M, Tomek W, Phatsara C, Alm H, Sirard MA, Kanitz W, Schellander K et al. 2008 Molecular and subcellular characterisation of oocytes screened for their developmental competence based on glucose-6-phosphate dehydrogenase activity. Reproduction 135 197-212. (doi:10.1530/REP-07-0348)

Valentini L, lorga AI, De santis T, Ambruosi B, Reynaud K, ChastantMaillard S, Guaricci AC, Caira M \& Dell'Aquila ME 2010 Mitochondrial distribution patterns in canine oocytes as related to the reproductive cycle stage. Animal Reproduction Science 117 166-177. (doi:10.1016/j. anireprosci.2009.03.008)

Van Blerkom J 2004 Mitochondria in human oogenesis and preimplantation embryogenesis: engines of metabolism, ionic regulation and developmental competence. Reproduction 128 269-280. (doi:10.1530/rep.1. 00240)

Van Blerkom J \& Runner MN 1984 Mitochondrial reorganization during resumption of arrested meiosis in the mouse oocyte. American Journal of Anatomy 171 335-355. (doi:10.1002/aja.1001710309)

Van Blerkom J, Davis PW \& Lee J 1995 ATP content of human oocytes and developmental potential and outcome after in-vitro fertilization and embryo-transfer. Human Reproduction 10 415-424. 
Van Blerkom J, Davis P \& Thalhammer V 2008 Regulation of mitochondrial polarity in mouse and human oocytes: the influence of cumulus derived nitric oxide. Molecular Human Reproduction 14 431-444. (doi:10.1093/ molehr/gan037)

Velilla E, Rodriguez-Gonzalez E, Vidal F, Izquierdo D \& Paramio MT 2006 Mitochondrial organization in prepubertal goat oocytes during in vitro maturation and fertilization. Molecular Reproduction and Development 73 617-626. (doi:10.1002/mrd.20426)

Wells D \& Patrizio P 2008 Gene expression profiling of human oocytes at different maturational stages and after in vitro maturation. American Journal of Obstetrics and Gynecology 198 455.e1-455.e11. (doi:10. 1016/j.ajog.2007.12.030)

Wongsrikeao P, Otoi T, Yamasaki H, Agung B, Taniguchi M, Naoi H, Shimizu R \& Nagai T 2006 Effects of single and double exposure to
Brilliant Cresyl Blue on the selection of porcine oocytes for in vitro production of embryos. Theriogenology 66 366-372. (doi:10.1016/j. theriogenology.2005.12.001)

Wu YG, Liu Y, Zhou P, Lan GC, Han D, Miao DQ \& Tan JH 2007 Selection of oocytes for in vitro maturation by Brilliant Cresyl Blue staining: a study using the mouse model. Cell Research 17 722-731. (doi:10.1038/cr. 2007.66)

Received 20 December 2010

First decision 3 February 2011

Revised manuscript received 7 June 2011

Accepted 7 July 2011 